\title{
Weight and age at puberty and their correlations with morphometric measurements in crossbred breed Suffolk ewe lambs
}

\section{Janine de Campos Ferra ${ }^{1}$, Silvia Cieslak ${ }^{2}$, Roberto Sartori Filho ${ }^{3}$, Connie McManus ${ }^{4}$, Carlos Frederico Martins ${ }^{5}$, José Robson Bezerra Sereno ${ }^{5}$}

\footnotetext{
1 Universidade Federal de Mato Grosso do Sul - Campo Grande, MS.

2 Universidade Federal de Mato Grosso do Sul - Campo Grande, MS.

${ }^{3}$ Embrapa Recursos Genéticos e Biotecnologia - Brasília, DF.

4 Universidade de Brasília - UnB - Brasília, DF.

${ }^{5}$ Embrapa Cerrados - Planaltina, DF.
}

ABSTRACT - The objective of this study was to identify and to correlate parameters that characterize puberty and estimate the age and weight of Suffolk ewe lambs in Mato Grosso do Sul. This study was carried out with twenty-two Suffolk ewe lambs for 256 days. Blood samples were collected from the jugular vein and centrifugated and the plasma were stored at $-20^{\circ} \mathrm{C}$ until analysis of progesterone $\left(\mathrm{P}_{4}\right)$ concentration by radioimmunoassay (RIA). The morphometric measurements included: head length and width, body length, elbow height, chest perimeter, back-sternal diameter, croup length, width and height, cannon bone perimeter and shoulder and hip width, using a tape. The animals became pubertal when the plasma progesterone concentration was $>1.0 \mathrm{ng} / \mathrm{mL}$, at $34.1 \pm 5.2 \mathrm{~kg}$ and $39.5 \pm 8.5$ weeks of age. Meanwhile, the lambs that did not reach puberty (37.7 \pm 11.4 weeks of age) were lighter. The morphometric measurements has medium to low correlations with age and weight at puberty.

Key Words: chest perimeter, progesterone, radioimmnunoassay, sheep

\section{Peso e idade à puberdade e suas correlações com medidas morfométricas em cordeiras mestiças Suffolk}

RESUMO - Os objetivos neste trabalho foram identificar e correlacionar parâmetros que caracterizem a puberdade e estimar a idade e o peso à puberdade de cordeiras mestiças Suffolk. Amostras de sangue de 22 borregas foram coletadas e centrifugadas e o plasma armazenado a $-20{ }^{\circ} \mathrm{C}$ para posterior análise das concentrações de progesterona $\left(\mathrm{P}_{4}\right)$ por meio de radioimunoensaio. As medidas morfométricas aferidas foram: comprimento e largura da cabeça; comprimento do corpo; altura de cernelha; perímetro torácico; diâmetro dorso-esternal; comprimento, altura e largura de garupa; perímetro de canela; e largura entre ísquios e ílios, utilizando-se fita métrica. Definiu-se como início da puberdade quando os animais apresentaram concentração plasmática de $\mathrm{P}_{4}>1,0 \mathrm{ng} / \mathrm{mL}$, o que ocorreu aos $34,1 \pm 5,2 \mathrm{~kg}$ de peso vivo e 39,5 \pm 8,5 semanas de idade. Entretanto, as cordeiras que não atingiram a puberdade (37,7 $\pm 11,4$ semanas de idade) apresentaram peso menor. As medidas morfométricas apresentam médias e baixas correlações com idade e peso à puberdade.

Palavras-chave: ovinos, perímetro torácico, progesterona, radioimunoensaio

\section{Introdution}

Rearing small ruminants is expanding in Brazil as diversification of animal production, to supply the national and international consumer market, so today Brazil is an importer of sheep meat. The Brazilian Middle West has 1.035.914 sheep, and thus it is the third sheep producing region in Brazil. Mato Grosso do Sul is the state with the largest number of animals in the region; from the year 2000, sheep rearing grew $22.6 \%$ and it was estimated at 463,473 heads in 2007, which represents $2.9 \%$ of the Brazilian flock (Anualpec, 2007).
Sheep breeding in Mato Grosso do Sul uses animals with greater aptitude for meat production. The wool also is exploited and is used in the regional craftwork or in riding accessories. Various sheep breeds are raised in the state, with the presence of crossbreeding involving two or more breeds, local breeds or without definite breed (WDB) are used for the dam base with the intention of making more productive small properties to diversify production and find a favorable herterosis for production of meat.

Physiological, nutritional and reproductive characteristics of sheep and their variation between breeds raised in Mato Grosso do Sul have been little reported. The 
reproductive performance of the females and lamb weight gain are responsible for the success of the production. The reduction in the lambing interval, anticipation of the age to the delivery and the nutrition management of the ewes are resources that make possible bigger kilogram production of lambs per ewe during its useful life, thus guaranteeing the growth of meat sheep breeding.

There is a growing demand by the productive and technical sector to identify sheep sexual precociousness, since this is the principal propelling factor for the implantation of selection and genetic improvement programs. Through the identification of precocious animals, which present puberty earlier and anticipate the moment of the first lambing, the reproductive life of these females is increased in the flock.

There is a linear and positive relation $(\mathrm{P}<0.01)$ between the concentration of blood progesterone ( $\mathrm{P} 4)$ and the number of corpus luteum formed. The differences in the levels of blood $\mathrm{P} 4$ are related mainly to the total luteal mass and not to the number of corpus luteum formed (Amiridis et al., 2002).

The objective of this study was to identify and correlated parameters that characterize puberty and to assess age and weight at puberty of Suffolk crossbreed ewes lambs in Mato Grosso do Sul.

\section{Material and Methods}

The study was carried out on the Guavira Farm (latitude $20^{\circ} 38$ ' 24.49" S, longitude 54 $43^{\prime} 25.44^{\prime \prime} \mathrm{W}$, altitude $478 \mathrm{~m}$ ), located at $30 \mathrm{~km}$ from the municipality of Campo Grande, Mato Grosso do Sul. The climate of the region is the tropical wet type with mean annual temperature of $26^{\circ} \mathrm{C}$ (minimum and maximum temperatures of $19^{\circ} \mathrm{C}$ and $38^{\circ} \mathrm{C}$, respectively). During the experimental period (256 days), the maximum and minimum temperatures were $10{ }^{\circ} \mathrm{C}$ and $38{ }^{\circ} \mathrm{C}$, respectively, with mean monthly rainfall of $200 \mathrm{~mm}$ and $60 \%$ relative mean air humidity during the experimental period (INMET, 2007).

Twenty-two crossbred females were used, derived from crosses with the Suffolk breed. The females born from single gestations in July, were weaned at two months of age and when they weighed $17.2 \pm 2.4 \mathrm{~kg}$, were fed in a feedlot to 4 months of age. In the feedlot the ewe lambs received total diet consisting of soy hull, soy meal, ground corn, dicalcium phosphate and sodium bicarbonate with $14 \%$ crude protein (PB), $62 \%$ total digestible nutrients (TDN) and $0.188 \mathrm{~g}$ calcium $\left(\mathrm{Ca}^{+2}\right)$ and $0.1 \mathrm{~g}$ of match $(\mathrm{P})$, and a portion equivalent to $6 \%$ was supplied on the natural matter broken up in three daily offers. At five months of age, these animals were transferred to Aruana paddocks (Panicum maximum Jacq. hp. Aruana), Brachiaria decumbens and native pasture, in a rotational system. All the animals had access to water and mineral salt ad libertum throughout the experimental phase.

The females were weighed monthly, from October 2006 to June 2007, during the morning period. The weights of the ewe lambs were checked after fast of 12 hours during the period in the feelot.

To take the morphometric measurements, a tape measure with precision of $1 \mathrm{~cm}$ was used. The checked measures included: head length and width; body length; elbow height; chest perimeter; back-sternal diameter; croups length, height and width; shin perimeter; shoulder and hip width (Brook et al., 2004) (Figure 1). These measurements were carried out monthly, from September 2006 to June 2007.

Blood samples were colleted from the jugular vein in heparinized vacutainer tubes with $25 \times 8 \mathrm{~mm}$ needle and the collections were carried out monthly from October to February and weekly from March to June 2007. The blood samples were centrifuged at $5000 \mathrm{rpm}$ for 15 minutes and the plasma stored in $1.5 \mathrm{~mL}$ polyethylene tubes and frozen at $-20{ }^{\circ} \mathrm{C}$ until the analyses. The plasma progesterone concentrations (P4) were analyzed by the solid phase radioimunoassay (RIA) method, using commercial kits (Coat-A-Count, DPC, Los Angeles, CA) following the directions of the manufacturer. The intra and inter-test coefficients of variation were $9.1 \%$ and $4.7 \%$, respectively. The hormonal tests were carried out in the Laboratory of Animal Reproduction at the Embrapa Recursos Geneticos e Biotecnologia in Brasília, Distrito Federal.

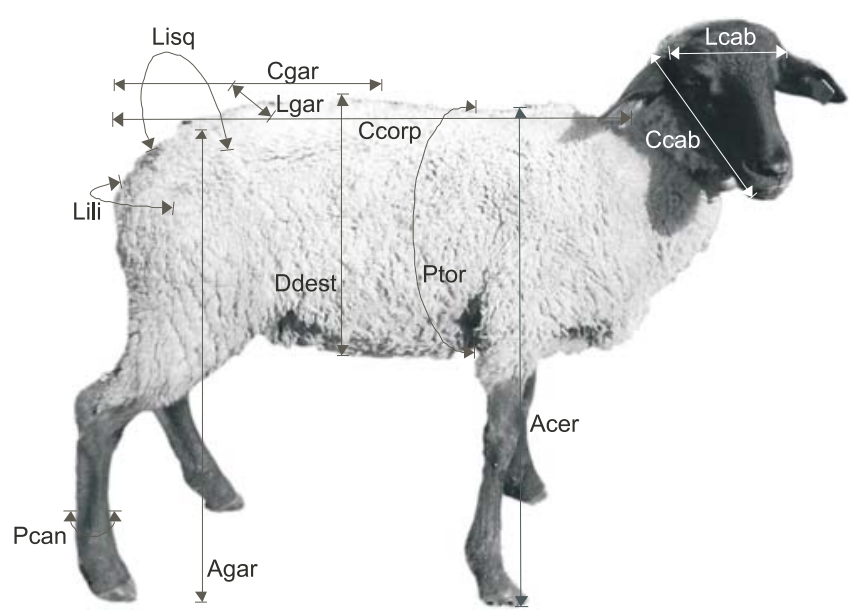

Ccab: head length; Lcab: head width; Ccorp: body length; Acer: elbow height; Ptor: thoracic perimeter; Ddest: back-sternal diameter; Cgar: rump length; Agar: height of rump; Lgar: rump width; Pcan: shin perimeter; Lisq: shoulder width; Lili: hip width.

Figure 1 - Mophometric measurements taken by tape measure with $1 \mathrm{~cm}$ precision. 
Puberty in each sheep was defined as the time when the progesterone plasma concentration was greater than $1.0 \mathrm{ng} / \mathrm{mL}$, that characterizes luteal activity (Milton et al., 1990).

The lambs at 33 weeks and mean weight of $31.2 \mathrm{~kg}$, were challenged to a fertility proof when subjected to two breeding seasons in a row with natural period of 45 days each, the first starting in February and the second in May. An adult ram was used with reproductive traits demonstrated by andrological examinations.

Gestation was diagnosed after 45 days of the end of each breeding season by transabdominal ultrasonography. The Digi-prince DP3300-vet(MINDRAY ${ }^{\circledR}$, USA) ultrasound apparatus was used with linear 7.5 MHz transabdonimal probe.

The data were analyzed using the general linear model (GLM) procedures where the differences between the characteristics of the growth between animals at puberty and not at puberty were testedat the end of the experiment, at $5 \%$ significance and compared using the Tukey test; CORR (correlations) and PRINCOMP (main) components of Statistical Analysis system ${ }^{\circledR}$ (SAS, 2001). Characteristics included in the analyses were progesterone plasma concentration; age at puberty; pregnancy (0/1); head length and width, body length; elbow height, chest perimeter; back-sternal diameter; length, croup height and width, shin perimeter, shoulder and hip width.

\section{Results and Discussion}

Six of the 22 ewe lambs evaluated were considered non-puberty because their $\mathrm{P} 4$ plasma did not rise during the evaluation period, i.e. between 10 and 49 weeks of age. The other sheep $(\mathrm{n}=16)$ presented $\mathrm{P} 4>1.0 \mathrm{ng} / \mathrm{mL}$ at some point within that period, the average age of puberty was $39.5 \pm 8.5$ weeks and the average weight was $34.2 \pm 5.2 \mathrm{~kg}$. The animals that did not reach puberty showed plasma P4 concentrations lower than $1.0 \mathrm{ng} / \mathrm{mL}$ and reached an average weight of $29.7 \pm 7.5 \mathrm{~kg}$ at the end of the experiment.

The mean age in this experiment (39.4 \pm 8.5 weeks) approached the values reported by Pappa-Michailidou et al. (1999) in the Greek breeds, Florina, Karagouniki that reached puberty at 40.4; 37.5 and 38.6 weeks of age, respectively. The values obtained in this study were similar to those observed in studies in the literature that where crossbred females reared in the United States that presented puberty at 25.4 weeks of age and $32.5 \mathrm{~kg}$ average weight (Boulanouar et al., 1995).

According to studies carried out by Bathaei (1996), Mehraban ewe lambs expressed first estrus at $30.3 \pm 1.0$ weeks and $44.3 \pm 1.9 \mathrm{~kg}$ and even thus were considered early compared to other breeds of sheep in that region of Iran, but they presented a shorter estrus than adult ewes and an irregular estrous cycle. Bartlewsky et al. (2002) used Suffolk ewe lambs in Canada and reported that these females came into puberty at 34 weeks and $49.9 \mathrm{~kg}$ average weight. Although the age was close to that reported in this study, the average weight at puberty of the crossbred females was $34.2 \pm 5.2 \mathrm{~kg}$ approximately $23 \%$ and $32 \%$ smaller than the weight described respectively by two last authors.

The ewe lambs that reached puberty presented greater $(\mathrm{P}<0.05)$ weight gain throughout the experimental period (Figure 2). However, the weight loss of these females at 26 weeks of age can be related to the adaptation period after changing the feedlot nutritional management for grazing.

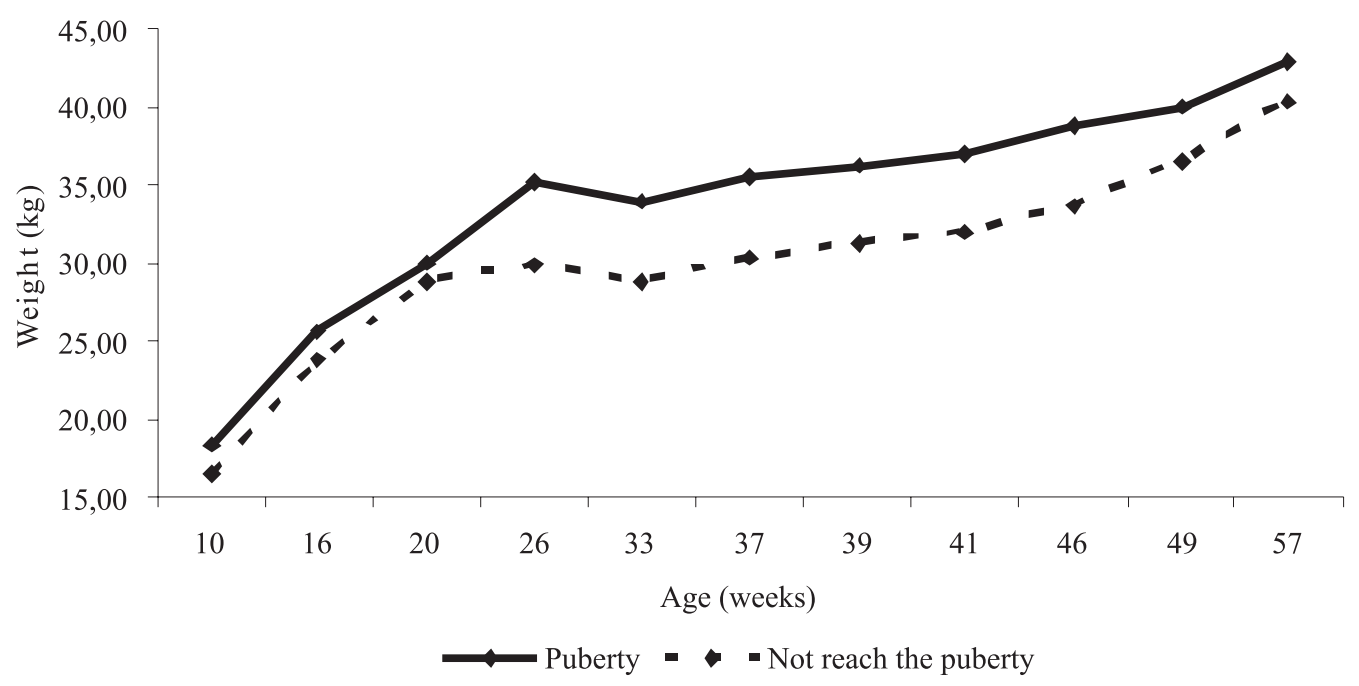

Figure 2 - Average age and weight of crossbred ewe lambs during the experimental period from October 2006 to August 2007. 
This weight gain could be constant if the females were confined and fed throughout the experimental period, reaching puberty earlier. As was reported by Maestá et al. (2006), the females of the Bergamacia breed kept in confinement (60\% coast-cross hay and $40 \%$ concentrate) reached puberty at 220 days of age. Whiles female kept in a feedlot up to 200 days of age and then submitted to grazing reached puberty at 386 days. Another study by Silva et al. (1988) reported that the age at puberty in ewes submitted to native grazing was $337.7 \pm 9.84$ days, while females entered puberty at $265.7 \pm 9.95$ days of age.

In this experiment all the females were from single pregnancies. According to Meredith \& Kiesling (1996), ewe lambs from twin gestation with prenatal development from another fetus female showed the first estrus at $29.0 \pm 0.8$ weeks, and when generated with the male fetus, that age was $30.0 \pm 0.4$ weeks, but this difference was not significant $(\mathrm{P}>0.05)$. At 30 weeks of age the animals weighed $49.0 \pm 1.0$ and $51.0 \pm 1.0 \mathrm{~kg}$ in the two groups, respectively.

Alves et al. (2006) described earlier lambs reared in The Federal District were born in August and reached puberty at $162.6 \pm 35.6$ days and $24.0 \mathrm{~kg}$ average weight, where puberty was defined when the semen presented total motility rate of over $10 \%$ and at least $50 \times 106^{6}$ sperm per $\mathrm{mL}$. Although born in the same season, females reared in Mato Grosso do Sul only reached puberty at $276.5 \pm 59.5$ days after presenting plasma progesterone concentration $>1.0 \mathrm{ng} / \mathrm{mL}$, indicating the first ovulation. However, ewe lambs reared in Cyprus, born during the fall, presented greater weight $(\mathrm{P}<0.01)$ than ewe lambs born during the winter in the same region, at 43.3 weeks and $50.1 \mathrm{~kg}$ and 29.9 weeks and $42 \mathrm{~kg}$, respectively (Papachristoforou et al., 2000). Other females of the Mouflon breed, born in Spain in the spring, grew rapidly, reaching puberty in the first season, the eight months of age and weight around $82 \%$ of the adult body weight of that breed. These results indicated the interaction between BW at puberty and lambing, because ewe lambs born in summer, that did not reach the minimum weight, come into puberty in the following breeding season at 19 months and $27.0 \pm 0.3 \mathrm{~kg}$ average weight (Moreno et al., 2000). Although subject to another photoperiods in different hemispheres and latitudes, crossbred females reared in Mato Grosso do Sul weighed on average $34.2 \pm 5.2 \mathrm{~kg}$.

Correlations were medium between head weight and length, age and elbow height, weight and elbow height, chest perimeter and body length, croup height and head length, croup height and elbow height (Table 1).

The other correlations were consideredlow and core component analysis was performed to better explain the variations between the characteristics at puberty. The first vector (x-axis) indicated that puberty was related to larger and heavier ewe lambs with higher progesterone plasma concentrations, as expected. In this first autovetor, elbow height and head length were smaller when the other characteristics were larger and vice-versa. The second autovetor (y-axis) indicated a subgroup with taller animals with more body weight and more precocity, but with little width (Figure 3). The difference between the size of the head in the female puberty and non-puberty groups can be related to the difference in the growth curve based on weight gain. Similarly, the differences between measurements of the elbow height and croup and the croup length and width can characterize a smaller female with less meat and fat deposited in the hindquarters.

In the study conducted by Mernies et al. (2007) in Uruguay, the Criolla breed ewes that had a tall and straight head were animals that had a circular than elliptical thoracic cross-section, indicating greater muscular capacity. In this experiment, the morphometric measurements of the Criolla breed were transformed to ethnologic indexes and productive skills-related indices (milk and meat capacity) to estimate the conformation of the flock and the meat production, keeping patterns of adaptation to the environmental conditions.

The 12 morphometric measurements determined during the experimental period were different $(\mathrm{P}<0.05)$ between ewe lambs groups that entered puberty and the ewe lambs considered non-puberty until the end of the trial period (Table 2).

Pena Blanco et al. (1990) reported that all measurements increase $(\mathrm{P}<0.05)$ with age in similar proportions, because age is the largest source of variation for the biometric measures. In females, the head grows in length and width based and thus as other measurements they indicate an elongation of the animals, making their trunk more compact. Regarding the croup, increasing distance between shoulders characterize a squarer female.

The animals' body conformation was defined by the relationship between the body height, length and depth, which vary according to breed and age. This is importante when the index of body capacity is identified with which fat deposition can be ascertained would be a good criterion of selection (Costa Jr. et al., 2006).

In the first months of life, ewe lambs that entered puberty in the experimental period, presented greater oscillation in plasma progesterone concentration values, followed by smaller variations for plasma progesterone concentration values of ewe lambs that did not reach puberty in the same period (Figure 4). A single ewe lamb began ovarian activity at 10 weeks, featuring plasma 
progesterone concentrations of $0.56 \mathrm{ng} / \mathrm{mL}$. At 16 weeks, the first ewe lamb puberty was observed presenting plasma progesterone concentration of $2.55 \mathrm{ng} / \mathrm{mL}$ (Figure 5).

At the beginning of the first breeding season only three ewe lambs had entered puberty and five females showed ovarian activity, at the end of this breeding season two ewe lambs were pregnant. The second breeding season started with 11 ewe lambs with luteal activity and ended with 15 pregnant ewe lambs. These ewe lambs showed $9.37 \mathrm{ng} / \mathrm{mL}$ plasma progesterone concentration, which were considered to be pregnant, confirmed by ultrasound images taken at 57 weeks.

Table 1 - Correlations between age, weight, progesterone concentration (ng/mL) and morphometric characteristics during the experimental period from October 2006 August 2007 in ewe lambs mestizos Suffolk

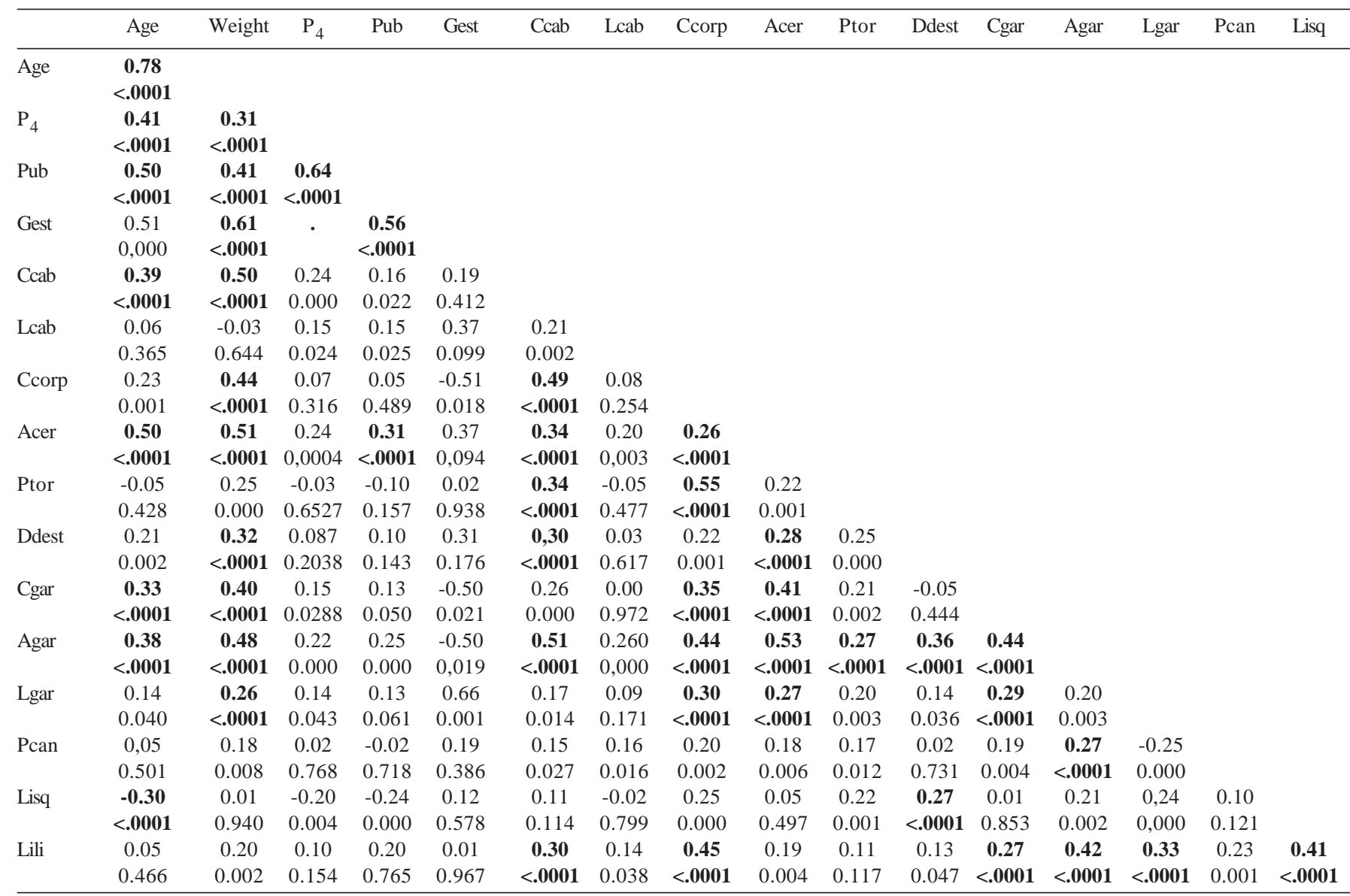

$\mathrm{P}_{4}$ : plasma progesterone concentration; Pub: puberty; Gest: gestation; Ccab: head length, Lcab: head width, Ccorp: body length; Acer: elbow height, Ptor: chest perimeter; Ddest: back-sternal diameter; Cgar: croup length, Agar: croup height, Lga: croup width, Pcan: shin diameter, Lisq: shoulder width; Lili: hip width.

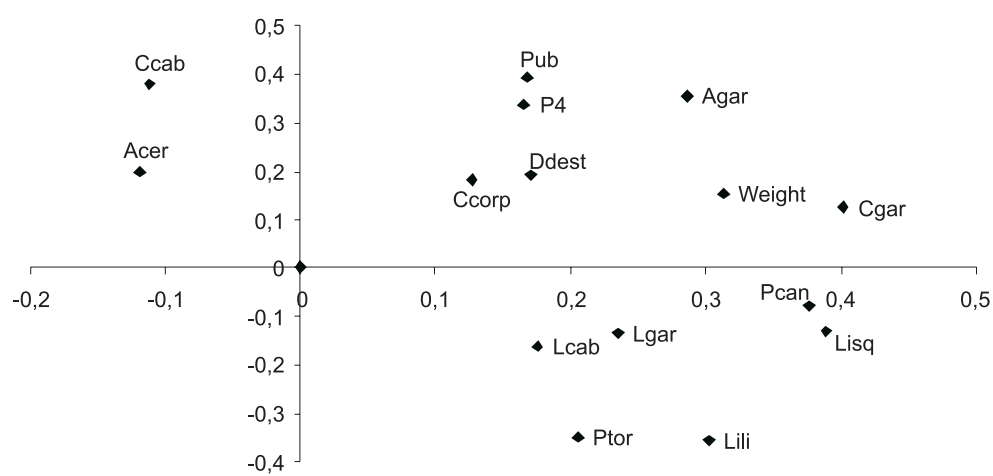

$\mathrm{P}_{4}$ : plasma progesterone concentration; Pub: puberty; Ccab: head length, Lcab: head width, Ccorp: body length; Acer: elbow height, Ptor: chest perimeter; Ddest: backsternal diameter; Cgar: croup length, Agar: croup height, Lga: croup width, Pcan: shin perimeter, Lisq: shoulder width; Lili: hip width.

Figure 3 - Core components (autovetor) for the features assessed at puberty in crossbred Suffolk ewe lambs reared in Mato Grosso do Sul. 
Table 2 - Morphometric measurementss of ewe lambs at 10 to 57 weeks of age reared in Mato Grosso do Sul

\begin{tabular}{lcc}
\hline Morphometric measurements $(\mathrm{cm})$ & Puberty ewe lambs $(\mathrm{n}=16)$ & Ewe lambs that did not reach puberty $(\mathrm{n}=6)$ \\
\hline Head Length & $21.0 \pm 1.3 \mathrm{a}$ & $20.5 \pm 1.4 \mathrm{~b}$ \\
Head Width & $15.0 \pm 1.4 \mathrm{a}$ & $14.4 \pm 4.7 \mathrm{~b}$ \\
Body Length & $71.5 \pm 3.6 \mathrm{a}$ & $71.0 \pm 5.3 \mathrm{a}$ \\
Elbow Height & $69.2 \pm 4.3 \mathrm{a}$ & $65.6 \pm 5.4 \mathrm{~b}$ \\
Chest perimeter & $79.8 \pm 6.8 \mathrm{a}$ & $81.3 \pm 8.3 \mathrm{a}$ \\
Back-sternal diameter & $50.7 \pm 3.8 \mathrm{a}$ & $49.8 \pm 4.3 \mathrm{a}$ \\
Croup Length & $41.4 \pm 5.7 \mathrm{a}$ & $39.9 \pm 5.2 \mathrm{~b}$ \\
Croup Height & $69.9 \pm 3.3 \mathrm{a}$ & $67.4 \pm 6.0 \mathrm{~b}$ \\
Croup Width & $29.2 \pm 2.7 \mathrm{a}$ & $28.4 \pm 3.3 \mathrm{~b}$ \\
Shin Perimeter & $10.5 \pm 0.7 \mathrm{a}$ & $10.5 \pm 1.7 \mathrm{a}$ \\
Shoulder width & $14.7 \pm 2.8 \mathrm{~b}$ & $16.7 \pm 3.7 \mathrm{a}$ \\
Hip width & $23.5 \pm 3.1 \mathrm{a}$ & $23.4 \pm 8.5 \mathrm{a}$
\end{tabular}

Means in the same line with different letters differ significantly $(\mathrm{P}<0.05)$ by Tukey test.

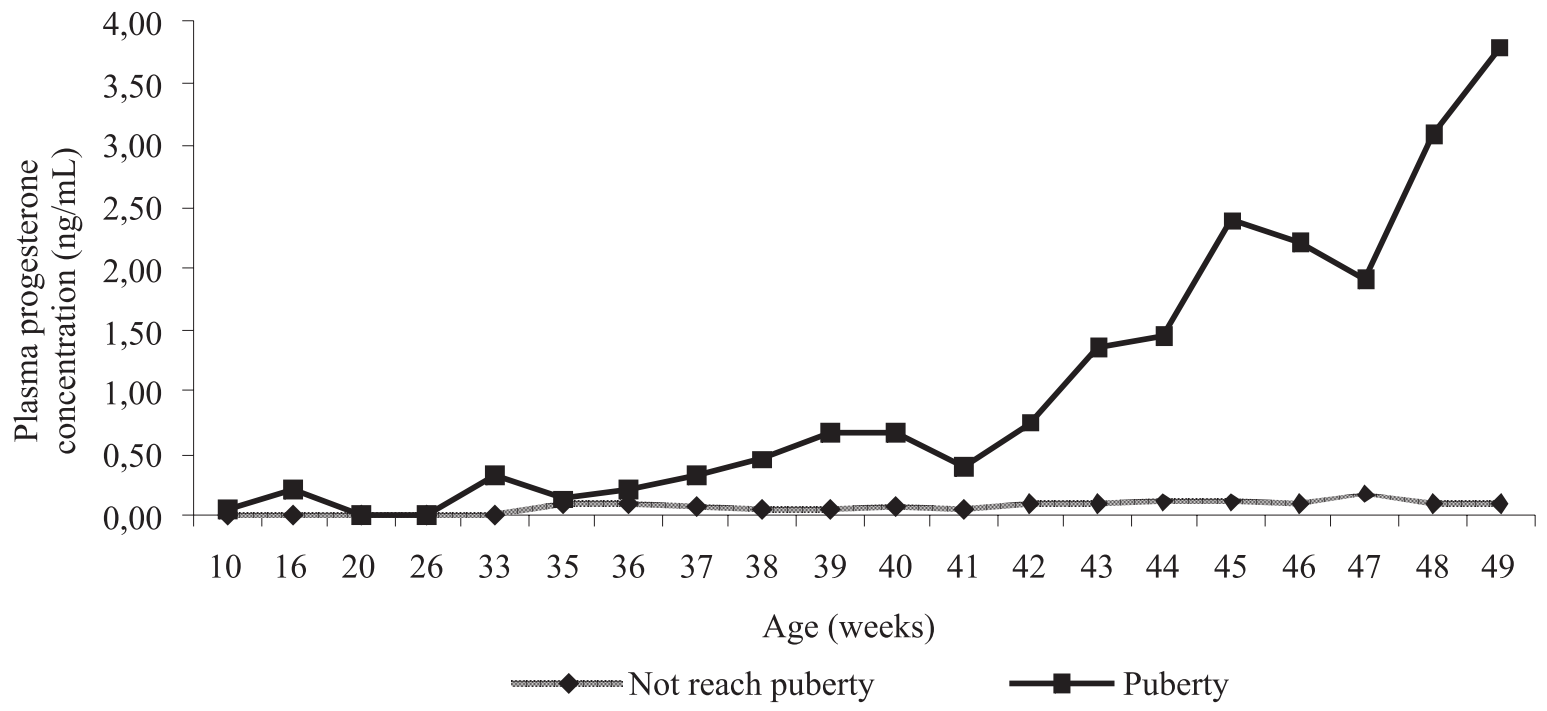

Figure 4 - Comparison of plasma progesterone concentration averages (ng/mL) observed in ewe crossbred lambs Suffolk creared in Mato Grosso do Sul.

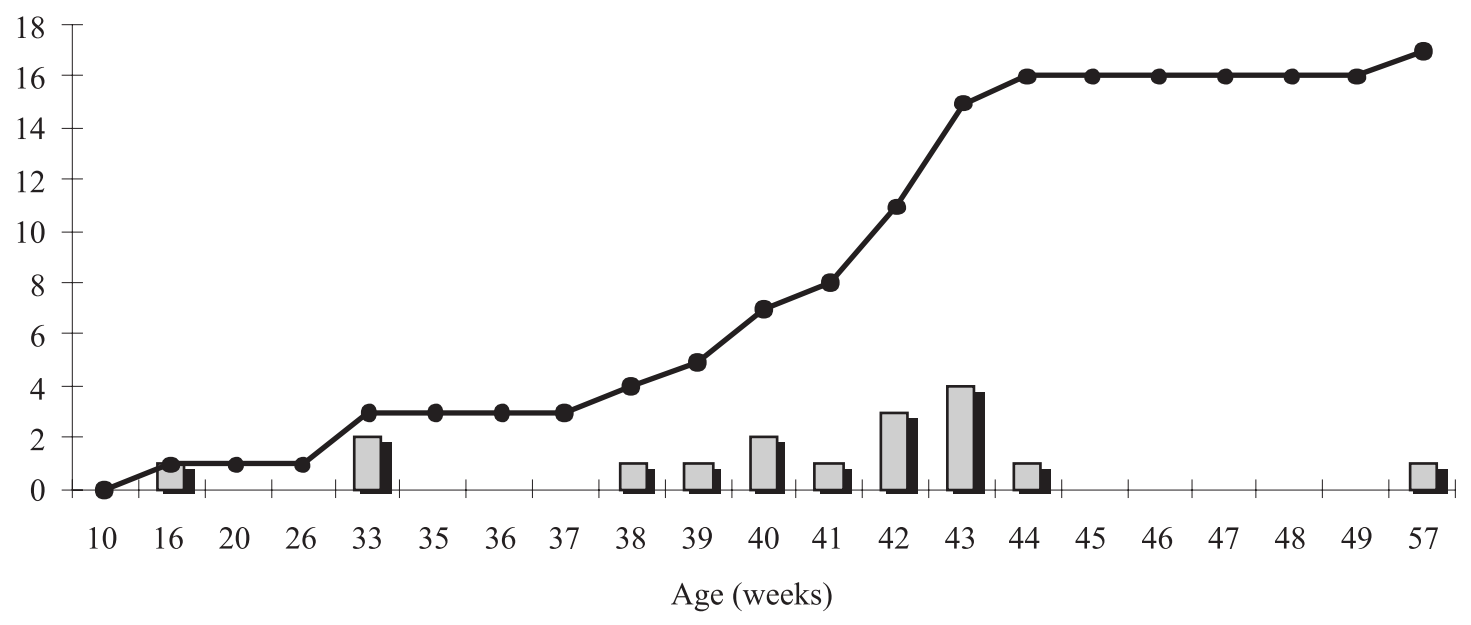

$\square$ Ewes lambs puberty $\rightarrow$ Total of ewes lambs puberty

Figure 5 - Number of crossbred Suffolk ewe lambs and age (weeks) reached puberty during the trial period from October 2006 to August 2007. 
According to Milton et al. (1990), values greater than $3.0 \mathrm{ng} / \mathrm{mL}$ characterize diestrus or pregnant. The anestrus phase differs from the estrus phase when progesterone concentrations remain low for more than 10 days (Sasa et al., 2002). However, the anestrus is the time that the progesterone concentration is less than $0.5 \mathrm{ng} / \mathrm{mL}$ (Sánchez et al., 2000). Considering that sheep are responsive to the photoperiod and because they are reared in a region where the photoperiod is less evident, lack of increase in plasma progesterone concentration may indicate that the animals are not sexually mature, because there is ovarian activity with variation in the values of the plasma progesterone concentration, or further, they are in seasonal anestrus if this concentration remains below $0.5 \mathrm{ng} / \mathrm{mL}$. According to Contreras-Solis et al. (2007), the plasma progesterone concentration is correlated with the CL diameter and area $(\mathrm{r}=0.60$ and 0.57 , respectively; $\mathrm{P}>0.01)$.

Of the 16 ewe lambs which reached puberty, 11 were diagnosed pregnant and five non-pregnant at the end of the two breeding seasons. Six ewe lambs not present plasma progesterone concentration $>1.0 \mathrm{ng} / \mathrm{mL}$ until the $49^{\text {th }}$ week of age, but a pregnant ewe lamb was diagnosed at 57 weeks of age. This female presented $0,79 \mathrm{ng} / \mathrm{mL}$ plasma progesterone concentration during the last week of the breeding season.

The presence of a ewe lamb diagnosed pregnant but without showing puberty, may indicate that the value established by Milton et al. (1990) is not suitable for females reared in Mato Grosso do Sul and to define another more expressive value, along with the blood collections, the ovaries should be examined by ultrasound, showing follicles and CL, laparoscopic surgery should be used to identify these structures.

\section{Conclusions}

It is recommended that ewe lambs crossbred Suffolk ewe lambs reared in Mato Grosso do Sul begin natural mating at 39 weeks age, on average, when these females should reach $34 \mathrm{~kg}$ mean body weight. Because it is the first report in the literature of the correlation between morphometric measurements and puberty in sheep, further studies are recommended using a larger number of animals to highlight those medium and low correlations, looking for a measurement, or a set of morphometric measurements, associated with puberty in this animal species.

\section{Acknowledgments}

The authors thank the participation of Lílian and Luis Carlos in the field collections and Fernanda and Lucas in the hormonal dosing process in the lab, as well as researchers who helped in the process. They also thank Beto and Ana Cristina from Guavira Farm for their confidence in this study.

\section{References}

ALVES, J.M.; McMANUS C.; LUCCI, C.M. et al. Estação de nascimento e Puberdade em cordeiros Santa Inês. Revista Brasileira de Zootecnia, v.35, n.3, p.958-966, 2006.

AMIRIDIS, G.S.; REKKAS, C.A.; FTHENAKIS, G.C. et al. Progesterone concentration as na indicator of ovarian response to superovulation in Chios ewes. Theriogenology, n.57, p.1143-1150, 2002.

ANUÁRIO DA PECUÁRIA BRASILEIRA - ANUALPEC. São Paulo: Instituto FNP, 2007. 368p.

BATHAEI, S. Breeding season and oestrus activity of Iranian fattailed Mehraban ewes and ewe lambs. Small Ruminant Research, n.22, p.13-23, 1996.

BARTLEWSKI, P.M.; BEARD, A.P.; COOK, S.J. et al. Ovarian activity during sexual maturation and following introduction of the ram to ewe lambs. Small Ruminant Research, v.43, p.37-44, 2002

BOULANOUAR, B.; AHMED, M.; KLOPFENSTEIN, T. et al. Dietary protein or energy restriction influences age and weight at puberty in ewe lambs. Animal Reproduction Science, n.40, p.229-238, 1995.

CONTRERAS-SOLIS, I.; DIAZ, T.; LOPEZ, G. et al. Systemic and intraovarian effects of corpus luteum on follicular dynamics during estrous cycle in hair breed sheep. Animal Reproduction Science, v.104, n.1, p.47-55, 2007.

COSTA JR., G.S.; CAMPELO, J.E.G.; AZEVÊDO, D.M.M.R. et al. Caracterização morfométrica de ovinos da raça Santa Inês criados nas microrregiões de Teresina e Campo Maior, Piauí. Revista Brasileira de Zootecnia, v.35, n.6, p.2260-2267, 2006.

INSTITUTO NACIONAL DE METERIOLOGIA - INMET. [2007] Disponível em: <http://www.inmet.gov.br>. Acesso em: 29/11/2007.

MAESTÁ, S.A.; SIQUEIRA, E.R.; STRADIOTTO, M.M. Idade à puberdade de cordeiros Bergamácias submetidos a dois sistemas de desmama. In.: SIMPÓSIO PAULISTA DE OVINOCULTURA, 7., 2006, Botucatu. Anais... Botucatu: Universidade Estadual Paulista, 2006

MEREDITH, S.; KIESLING, D.O. Age of puberty in ewes which developed prenatally with either a ram or a ewe fetus. Small Ruminant Research, v.20, p.137-140, 1996.

MERNIES, B.; MACEDO, F.; FILONENKO, Y. et al. Índices zoométricos em uma muestra de ovejas Criollas uruguaias. Archivos de Zootecnia, n.56, n.1, p.473-478, 2007.

MILTON, J.E.; COPPINGER, T.R.; SPAETH, C.W. et al. Poor reproductive response of anestrous Suffolk ewes to ram exposure is not due to failure to secrete luteinizing hormone acutely. Journal of Animal Science, v.69, p.3314-3320, 1990.

MORENO, J.S.; BRUNET, A.G.; BULNES, A.G. et al. Attainment of puberty in the European Mouflon (ovis gmelini musimom) and the domestic manchega ewe (Ovis aries). Reproduction in Domestic Animals, v.31, n.2, p.49, 2000.

PAPACHRISTOFOROU, C.; KOUMAS, A.; PHOTIOU, C. Seasonal effects on puberty and reproductive characteristics of female Chios sheep and Damascus goats born in autumn or in February. Small Ruminant Research, n.38, p.9-15, 2000.

PAPPA-MICHAILIDOU, V.; AVDI, M.; ZAFRAKAS, A. et al. Prepubertal plasma FSH concentrations and their relationship with reproductive performance in three Greek breeds of sheep. Small Ruminant Research, n.33, p.37-41, 1999.

PEÑA BLANCO, F.; DOMENECH GARCÍA, V.; APARICIO RUIZ, F. et al. Estúdio biométrico em lar aza ovina segureña. Archivos de Zootecnia, n.39, p.249-261, 1990. 
RIBEIRO, N.L.; MEDEIROS, A.N.; RIBEIRO, M.N. et al. Estimación del peso vivo de caprinos autóctonos brasileños mediante medidas morfométricas. Archivos de Zootecnia, n.53, p.341-344, 2004.

SÁNCHEZ, L.; FERNÁNDEZ, B.; LÓPEZ, M. et al. Caracterización y orientaciones productivas de lar aza ovina Gallega. Archivos de Zootecnia, n.49, p.167-174, 2000.

SASA, A.; TESTON, D.C.; RODRIGUES, P.A. et al. Concentrações plasmáticas de progesterona em borregas lanadas e deslanadas no período de abril a novembro, no Estado de São Paulo. Revista Brasileira de Zootecnia, v.31, n.3, p.1150-1156, 2002.

SILVA, A.E.D.F.; NUNES, J.F.; RIEIRA, G.S. et al. Idade, peso e taxa de ovulação à puberdade em ovinos deslanados no Nordeste do Brasil. Pesquisa Agropecuária Brasileira, v.23, n.3, p.271-283, 1988.

STATISTICAL ANALYSES SYSTEM - SAS. User's guide. Cary: SAS Institute Inc., 2001. (CD-ROM). 